\author{
M. Bondarenko, PhD (Geol.), Senior Researcher, \\ V. Kulyk, PhD (Phys.-Math.), Leading Researcher \\ E-mail: vkulyk@igph.kiev.ua, \\ Z. Yevstakhevych, Leading Engineer \\ Institute of Geophysics National Academy of Sciences of Ukraine \\ 32 Palladin Ave., Kiev, 03680, Ukraine
}

\title{
PETROPHYSICAL PARAMETERS OF NEAR-SURFACE SANDSHALE ROCKS BASED ON RADIOACTIVE LOGGINGS
}

\begin{abstract}
(Рекомендовано членом редакційної колегії д-ром геол. наук, проф. О.М. Карпенком)
The apparatus-methodical complex of radioactive logging (AMC RL) for determining set of petrophysical parameters of near-surface sandshale rocks is developed. AMC RL includes gamma-ray logging (GL), neutron-neutron logging (NNL), gamma-gamma logging (GGL); radioactive logging apparatus; interpretating-methodical support and software.

In the general case, petrophysical parameters of rocks can be determined by combining the measured parameters of the radioactive logging with the use of a number of a priori data. AMC RL allows to determine: parameters of density, shaliness, porosity, volume moisture content, groundwater level, etc. A number of new techniques for determining these parameters by nuclear geophysical methods are proposed. The features of obtaining parameters in the zone of full water saturation and in the aeration zone are shown. A number of parameters were first determined using geophysical well logging.

A set of two-channel tools $2 N N L$ and $G G L+G L$ as well as a three-component tool $2 N N L+G G L+G L$, which meet modern requirements, have been developed, produced and tested.

Efficiency of the developed approaches and tools is demonstrated by the example of determination of petrophysical parameters in cased well.
\end{abstract}

Keywords: near-surface rocks, petrophysical parameters;, combination of gamma-ray logging, neutron-neutron logging and gammagamma logging; radioactive logging apparatus, shaliness, density, porosity, volume moisture content, water saturation.

Introduction. The construction of important buildings for various purposes, dams, gas and oil pipelines, engineering services and other objects necessitates a detailed study of the features of the geological structure of near-surface rocks. For solving the problems of engineering geology, geophysical investigations of rocks in the section of wells, namely the combination of integral gamma-ray logging (GL), neutron-neutron logging (NNL) and gamma-gamma density logging (GGL), is effective.

The apparatus-methodical complex of radioactive logging (AMC RL), which is developed in Institute of Geophysics NAS of Ukraine (IGPH), includes radioactive logging apparatus and corresponding interpretating-methodical support and software. AMC RL allows determining a wide range of petrophysical parameters of near-surface rocks in both cased and uncased wells. The main petrophysical parameters include the following: rock density, mass and volume shaliness, mass and volume content of clay minerals, porosity, volume moisture content, water saturation, groundwater level.

The determination of petrophysical parameters by the combination of radioactive loggings has its features for aeration zone and zone of full water saturation. The fact that the near-surface rocks of most of the territory of Ukraine are sandshale rocks is taken into account.

Below the main elements of a new methodology for the integrated determination of parameters of near-surface rocks by radioactive logging methods using a number of a priori data, advantages of new AMC RL are shown.

Petrophysical model, conditions of measurements. The near-surface sandshale rock consists of a solid phase and pores. The pores are filled with water and air in various proportions. The volume moisture of the rock is determined as $W_{V}=S_{W} \phi$, where $\phi$ is the porosity (ratio of pore volume to rock volume), $S_{w}$ is water saturation, which can vary from 0 (dry rock) to 1 (full water saturation). By the aeration zone we mean part of the section, which is above the groundwater level $\left(S_{w}<1\right)$; below this level the rocks are completely saturated with fresh water $\left(S_{w}=1, \phi=W_{V}\right)$.

The solid phase of sandshale rock consists of quartz and shaly material (total shaliness). Shaly material includes quartz particles and clay minerals (kaolinite, montmorillonite, and hydromicas). Total shaliness and content of clay minerals are important parameters for engineering geology. Since the average value of the clay minerals density usually differs little from the quartz density, the density of the solid phase of the rock $\rho_{s}$ is considered to be known (as well as the density of fresh water $\rho_{w}$ ). The relationship between the bulk rock density $\rho$, the density of the solid phase $\rho_{\mathrm{s}}$, the water density $\rho_{\mathrm{w}}$, the porosity $\phi$ and the volume moisture $W_{v}$ is as follows: $\rho=\rho_{s}(1-\phi)+\rho_{w} W_{v}$.

Radioactive logging is performed in a dry cased hole when the tool moves from the bottom of well to the wellhead. Diameter of steel casing equals 2 inch $(51 \mathrm{~mm})$, wall thickness equals $5,5 \mathrm{~mm}$; casing is close to the rock. The wells range in depth from several meters to the first tens of meters. Thermobaric conditions of occurrence correspond to normal $P T$-conditions and, within the depth of the performed well investigations, practically do not affect the determined parameters.

Apparatus. An integral component of the AMC RL is logging apparatus for near-surface investigations, developed in IGPH.

In Ukraine the existing technology of engineeringgeophysical investigations, which uses $R L$, is based on a commercial set of single-spacing tools, namely, the neutronneutron moisture meter VPGR-1 [1] and gamma-gamma density meter PPGR-1 [13]. Tools and their metrological and methodical support, which were developed as far back as the 80 s of the last century, have a number of shortcomings when carrying out borehole measurements and obtaining petrophysical parameters, namely:

- the need to perform triply logging run for the registration of $\mathrm{GL}, \mathrm{GGL}, \mathrm{NNL}$, which reduces the productivity and efficiency of investigations;

- the impossibility to carry out the operational adjustment and control of detector signals;

- an outdated unit for registration of measurements: the tool readings are noted on paper manually, and then they are typed into the computer;

- the absence of techniques for determining the parameters of the shaliness;

- neglect of the effect of chemically bound water in clay minerals in determining porosity and moisture;

- an uncontrolled effect of anomalous and strong thermal neutron absorbers $(\mathrm{Li}, \mathrm{B}, \mathrm{Cl}, \mathrm{Ti}, \mathrm{Mn}, \mathrm{K}, \mathrm{Fe}$, rare earth elements) on the readings of the NNL detector; the aforementioned elements may be present in the investigated geological section and lead to essential errors in determining moisture and other parameters. 
An integral part of the traditional technology is a set of aluminum-plexiglass simulators of density and moisture, which are used to obtain the calibration dependences of GGL and NNL. But these simulators do not always reflect the real properties of the investigated rocks, in particular in the case of natural sandshale rocks.

Thus, the problem of creating a new AMC RL, based on the current level of scientific developments, modern elemental base and appropriate level of recording, storing and transferring information, as well as on more adequate methodological and metrological support, is topical.

The IGPH has developed and produced a set of twochannel radioactive logging tools [8, 9], which remove the main shortcomings of the commercial tools. The set consists of a two-channel tool GGL+GL and a two-channel (dualspacing) tool 2NNL.

Addition of the GL sensor to the GGL tool allows reducing the number of trip, that is, labor productivity increases. Wherein the GL detector performs a dual function: 1) integral registration of natural gamma radiation and 2) takes into account the natural background in the readings of the GGL detector.

The equipping of the NNL tool with the second neutron detector makes it possible to determine the moisture in two ways: single-spacing and compensated (by the ratio of the readings of the two detectors). Compensated neutron logging [14], in particular, allows determining moisture content in the presence of anomalous neutron absorbers in the rock.

Features of the new dual-spacing tools are as follows.

- The design of the base sondes of VPGR-1 and PPGR1 in the new tools is left unchanged so that it is possible, at a transitional stage, to use both the traditional approach and the new AMC RL.

- The well-logging cable is single-core, in contrast to the three-core cable in the commercial tools. Such a cable can be up to 70 meters or more. In new tools, the cable is removable, that is, one cable is used for both tools (in VPGR-1 and PPGR-1 the cable is not disconnected from the borehole device).

- The surface control and registration panel is constructed on the base of modern electronic components [9].

- The pulse discriminator is displaced from the downhole device to the surface control panel. It makes possible carrying out adjustment and control the sensor signals with an oscilloscope in the laboratory

- In the surface control panel there is a microprocessor for recording and processing informative pulses.

- The ground console has a flash memory for storing, reproducing and transfer information through the serial port to the computer for further interpretation of measurements.

Fig. 1 gives a photo of a set of two-channel radioactive logging tools, which are produced in IGPH.

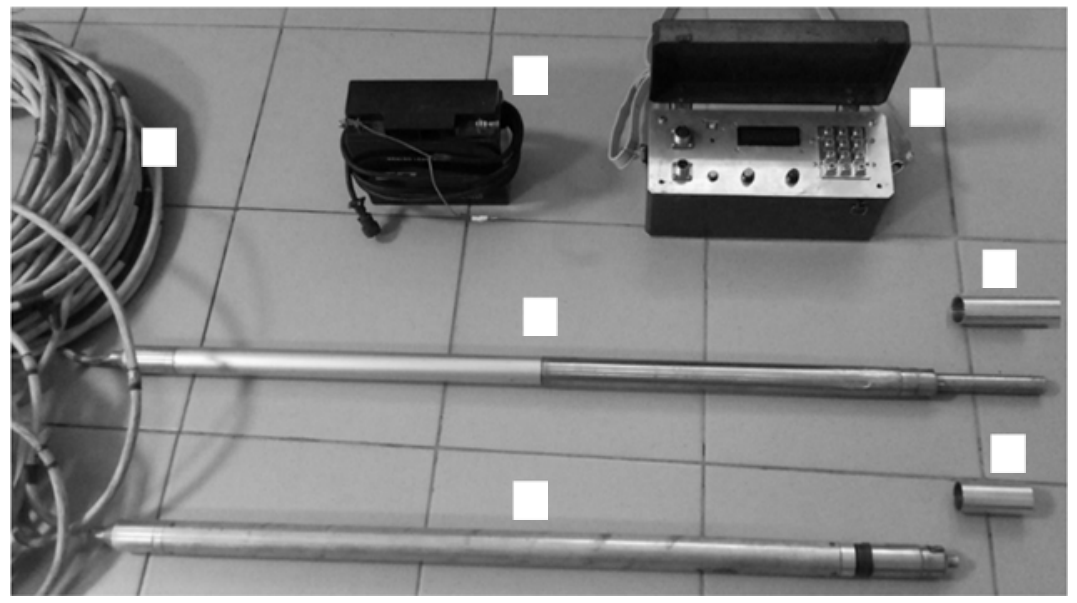

Fig. 1. Set of experimental two-channel radioactive logging tools:

1 - dual-spacing tool 2NNL; 2 - two-channel tool GGL+GL; 3 - detachable neutron source chamber;

4 - detachable gamma-ray source chamber; 5 - surface control and registration panel; 6 - accumulator; 7 - well-logging cable

Three-component radioactive logging tool (TRL), created in IGPH [6], unionizes all the advantages of a set of dual-channel tools. The TRL tool contains two NNL sondes, GGL sonde and a GL sonde. Sondes are located along the tool so that the NNL and GGL sondes have no interaction and do not affect the GL; the length of the tool at the given power of the sources of neutrons and gamma ray is chosen to be smallest.

The fundamental advantage of the TRL tool is the obtaining results of all three used radioactive logging methods in a single trip; this increases labor productivity, reduces the work time at the well.

Measured parameters and calibration dependencies

Directly recorded quantities are the following: count rate of gamma quantums of natural radiation along the borehole section $\left(l_{\gamma}\right.$, counts per second $\left.(\mathrm{cps})\right)$; count rate of Compton gamma quantums arising as a result of interaction gammaray from the ${ }^{137} \mathrm{Cs}$ source with rock $\left(I_{\gamma \gamma}, \mathrm{cps}\right)$; count rate of slow neutrons produced as a result of slowing and diffusion of neutrons from the ${ }^{238} \mathrm{PuBe}$ source $\left(I_{\mathrm{nn}}, \mathrm{cps}\right)$.

Shaliness-related measured parameters are the total mass shaliness $C_{\text {sh }}$ and the mass content of clay minerals $C_{\mathrm{cl}}$. These parameters are determined from the laboratory data. Using the correlation relationship between the shaliness parameters and the corresponding data of gamma-ray logging in the form of relative difference parameter $\Delta l_{\gamma}[5,12$, 16], we obtain the calibration curves of gamma-ray logging [7]:

$$
\Delta I_{\gamma}=f_{\mathrm{sh}}\left(C_{\mathrm{sh}}\right), \quad \Delta I_{\gamma}=f_{\mathrm{cl}}\left(C_{\mathrm{cl}}\right) .
$$

Fig. 2 shows the corresponding dependencies and their form in terms of polynomials. 


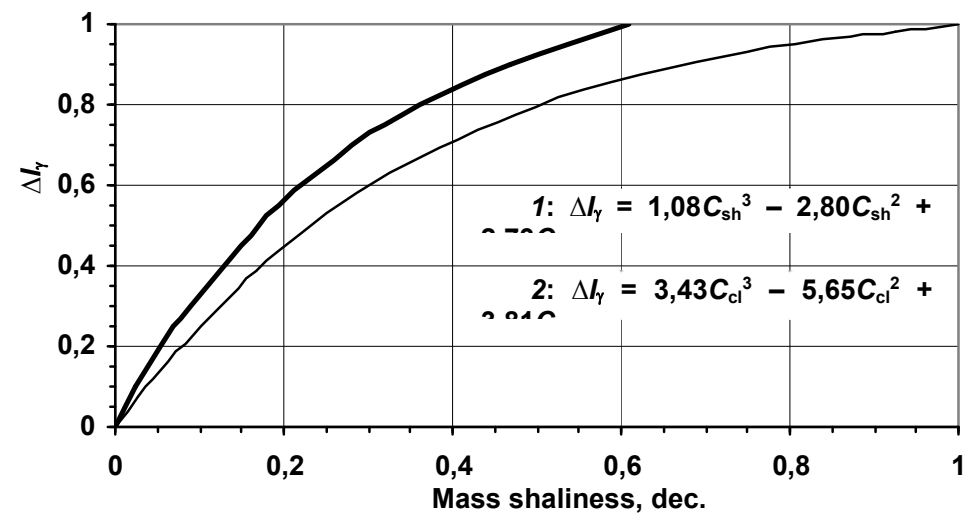

Fig. 2. Calibration dependences of gamma-ray loggingfor determination of total mass shaliness (1) and mass content of clay minerals (2). dec. - decimal

When investigating the near-surface sandshale rocks, it is advantageous to calibrate the readings of density logging tool and neutron logging tool using clean (nonshale) water-saturated quartz sand model with different porosity. From the data of modeling, we obtain the calibration dependences for both gamma-gamma density logging and neutron-neutron logging:

$$
B_{\gamma \gamma}=f_{\mathrm{GGL}}\left(\rho^{\gamma \gamma}\right) \text {, }
$$

where $B_{r y}$ is readings of GGL in relative ("water") units;

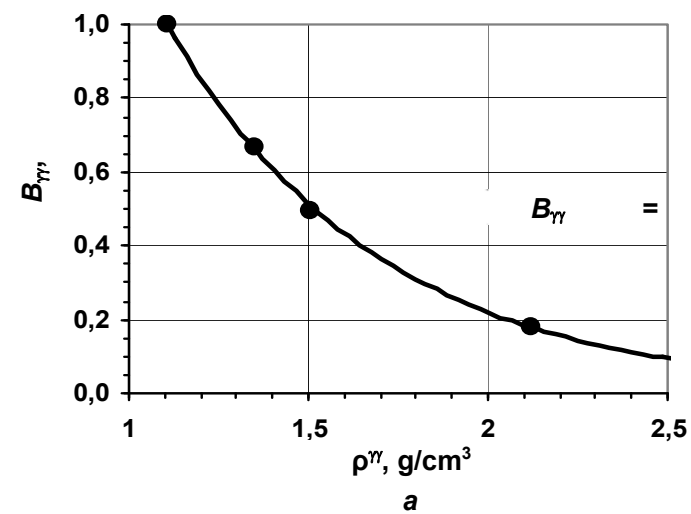

$$
B_{\mathrm{nn}}=f_{\mathrm{NNL}}\left(\phi^{\mathrm{nn}}\right) \text {, }
$$

where $B_{\mathrm{nn}}$ is readings of NNL in relative ("water") units.

The use of relative units makes it possible to obtain correct results when measuring with the one-type of NNL and GGL tools with corresponding sources of different power, and for NNL we also take into account the change in the efficiency of ${ }^{3} \mathrm{He}$-detectors of neutron with time.

Fig. 3 gives the calibration dependencies for twochannel RL tools created in the IGPH. In Fig. 3 are shown calibration curves for the GGK (GGL+GK tool) and for near neutron detector of 2 NNL tool. Calibration dependencies are obtained on physical models constructed in IGPH.

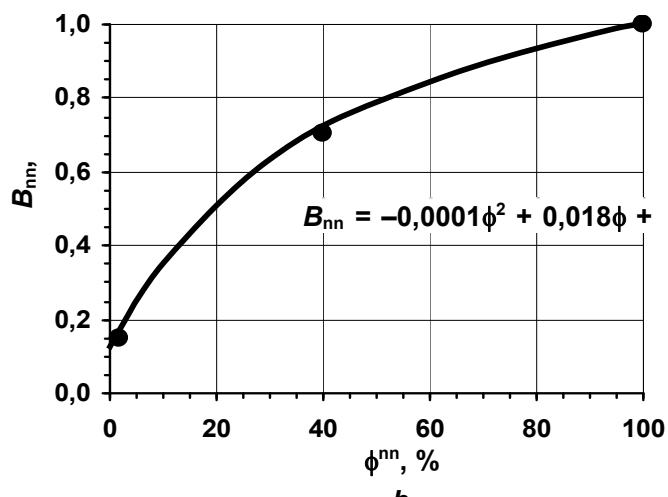

Fig. 3. Calibration dependencies: gamma-gamma logging for GGL+GL tool (a); neutron-neutron logging for near detector of $2 \mathrm{NNL}$ tool (b).

- - data of measurements on physical models IGPH; r.u. - relative unit

Shaliness. Shaliness is an important lithological characteristic of rocks. There is a distinction between the total shaliness of the rock and the clayiness. Clayiness is associated only with the content of clay minerals. The filtration properties (permeability) of the rock depend on the total shaliness. The content of clay minerals and their type affect the physical-mechanical properties of rocks. Chemically bound water, which is contained in clay minerals, has a significant affect on NNL readings. It must be taken into account when determining the porosity and moisture content of the rocks under investigation by NNL. The characteristic features of individual clay minerals and their mixtures are the hydrogen index and density.

The total mass shaliness and the mass content of clay minerals are determined by interpretation dependencies, which are the inverse functions of the calibration dependencies (1). For the calibration curves of the GL, which are shown in Fig. 2, the corresponding interpretation relationships are the following:

$$
\begin{gathered}
C_{\mathrm{sh}}=2,60 \Delta I_{\gamma}^{4}-3,55 \Delta I_{\gamma}^{3}+1,78 \Delta I_{\gamma}^{2}+0,15 \Delta I_{\gamma}, \\
C_{\mathrm{cl}}=0,74 \Delta I_{\gamma}^{4}-0,84 \Delta I_{\gamma}^{3}+0,51 \Delta I_{\gamma}^{2}+0,20 \Delta I_{\gamma} .
\end{gathered}
$$

Mass parameters $C_{\text {sh }}$ and $C_{\text {cl }}$ practically do not depend on the zone in which they are determined - full water saturation zone or aeration zone.

Analysis and interpretation of well logging data uses total volume shaliness and volume content of clay minerals [2]:

$$
K_{\mathrm{sh}}=C_{\mathrm{sh}}(1-\phi), \quad K_{\mathrm{cl}}=C_{\mathrm{cl}}(1-\phi),
$$

where $\phi$ is total porosity. 
The content of chemically bound water, $C_{\text {c.b.w. }}$ in clay minerals is determined as

$$
C_{\text {c.b.w. }}=\omega_{\mathrm{cl}} K_{\mathrm{cl}} \text {, }
$$

where $\omega_{c l}$ is hydrogen index of clay minerals $[3,5,18]$.

When there is full water saturation, the parameter $C_{\text {c.b.w. }}$ is the difference between the "neutron" porosity (hydrogen content) by the NNL and the porosity by the GGL:

$$
C_{\text {c.b.w. }}=\phi^{\mathrm{nn}}-\phi^{\gamma \gamma},
$$

where $\phi^{\text {nn }}$ is "neutron" porosity by the NNL; $\phi^{r \gamma}$ is total porosity by the GGL.

Fig. 4 shows the interdependence of the parameters $C_{\text {c.b.w. and }} \Delta l_{\gamma}$, obtained on the basis of borehole measurements in the near-surface sandshale rocks. Rather close correlation between the content of clay minerals (through the content of chemically bound water) and the relative difference parameter of the $\mathrm{GL}$ is seen.

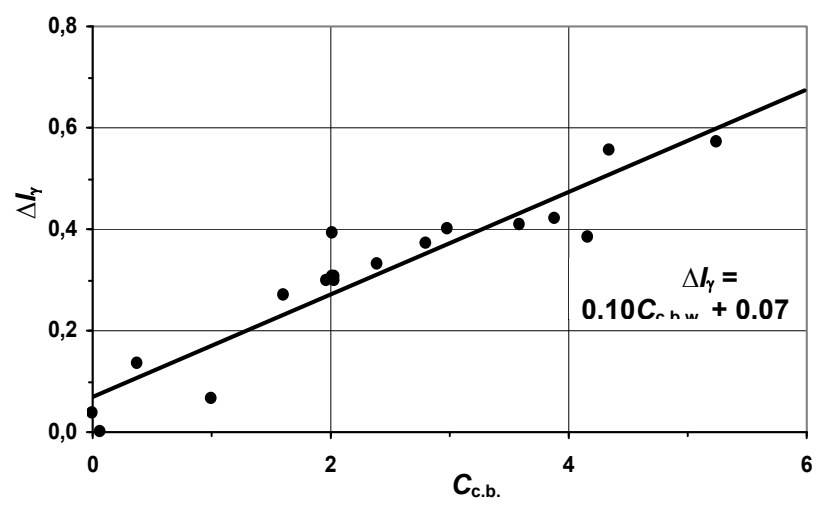

Fig. 4. Relationship between the content of chemically bound water in clay minerals and relative difference parameter

Hydrogen index of clay minerals, in turn, can be obtained from formulas (7) and (8), knowing the parameters $\phi^{\mathrm{nn}}, \phi^{\gamma \gamma}$ and $K_{\mathrm{cl}}$ :

$$
\omega_{\mathrm{cl}}=\left(\phi^{\mathrm{nn}}-\phi^{\gamma \gamma}\right) / K_{\mathrm{cl}} \text {. }
$$

The density of clay minerals in the zone of full water saturation of terrigenous (sandshale) rock can be estimated by the combination of radioactive loggings [10]:

$$
\rho_{\mathrm{cl}}=\frac{1}{K_{\mathrm{cl}}}\left(\rho^{\gamma \gamma}-\rho_{\mathrm{qu}}\left(1-\phi-K_{\mathrm{cl}}\right)-\rho_{\mathrm{w}} \phi\right),
$$

where $\rho^{\gamma /}$ is total rock density by GGL; $\rho_{q u}$ is quartz density, accepted as $2,65 \mathrm{~g} / \mathrm{cm}^{3}$; $\rho_{\mathrm{w}}$ is formation water density, equal $1,00 \mathrm{~g} / \mathrm{cm}^{3}$.

It is important to obtain information about the type of clay minerals that are contained in sandshale rock, since these minerals can affect the rock properties as the basis of building structures. For example, montmorillonite is characterized by strong swelling and plasticity, while hydromicas weakly absorb water [15]. For the identification of clay minerals laboratory methods are used. This involves the rock sampling and carrying out of labor-intensive and costly studies [4].

The density $\rho_{\mathrm{cl}}(10)$ and the hydrogen index $\omega_{\mathrm{cl}}(9)$ of clay minerals are related to their type. Therefore in favorable cases it is possible to estimate the type of clay mineral in layer or its predominant content in the mixture by the comparison of the layer parameters $\rho_{\mathrm{cl}}$ and $\omega_{\mathrm{cl}}$, obtained from the results of $\mathrm{RL}$ along the borehole section. Fig. 5 gives crossplot $\rho_{\mathrm{c}} \Leftrightarrow \omega_{\mathrm{cl}}$, which is constructed on the materials of borehole measurements in sandshale rocks, and demonstrates the results of this approach.

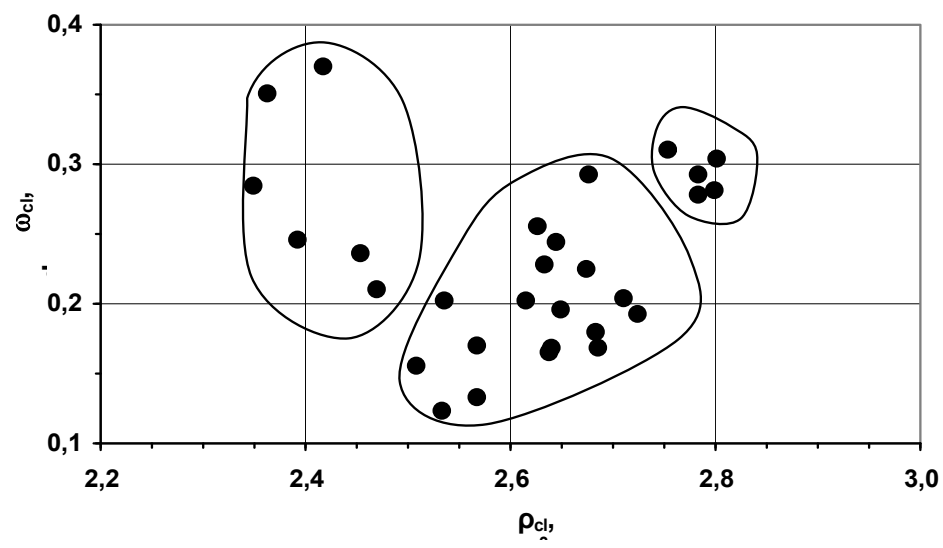

Fig. 5. Crossplot of density and the hydrogen index of clay minerals for estimation of their type: 1 - montmorillonites, 2 - mixture of minerals, 3 - chlorite

Density. The result of the gamma-gamma density logging, $\rho^{\gamma /}$, is determined by the electronic density of the rock, which, in turn, is closely related to the bulk density $\rho$. For sandshale rocks equality $\rho^{\gamma / \gamma}=\rho$ is correct with a sufficiently high accuracy for practice (with an error not more than $0,01 \mathrm{r}^{\mathrm{cm}}{ }^{3}$ ) [5].

The rock density by the GGL is determined from the interpretation dependence, which is the inverse function of 
the calibration curve (2). For the $G G \mid+G L$ tool, the corresponding interpretation dependence is expressed as

$$
\rho^{\gamma \gamma}=-0,59 \ln \left(B_{\gamma \gamma}\right)+1,11 \text {. }
$$

The relation between density $\rho^{\gamma}$, solid phase density $\rho_{\mathrm{s}}$, water density $\rho_{w}$ and water-saturated porosity $\phi$ is as follows:

$$
\rho^{\gamma \gamma}=\rho_{\mathrm{s}}(1-\phi)+\rho_{\mathrm{w}} \phi \text {. }
$$

Porosity. Porosity by GGL (density porosity) in full water saturation zone is expressed in terms of density $\rho^{w}$ from (12) as

$$
\phi^{\gamma \gamma}=\frac{\rho_{\mathrm{s}}-\rho^{\gamma \gamma}}{\rho_{\mathrm{s}}-\rho_{\mathrm{w}}} .
$$

Porosity by GGL in aeration zone is formally expressed by the same formula. But it is overstated through the decrease in density $\rho^{\gamma \gamma}$ due to the presence of air in the pores, that is, the porosity by GGL in the aeration zone is apparent.

Porosity by NNL (neutron porosity) is determined from the interpretation dependence, which is the inverse function of the calibration curve (3). For a near-spacing detector of a dual-spacing tool $2 \mathrm{NNK}$, the corresponding interpretation dependence for $\phi<50 \%$ is expressed as

$$
\phi^{\mathrm{nn}}=73,05 B_{\mathrm{nn}}^{2}+6,00 B_{\mathrm{nn}}-1,00 .
$$

Porosity by $N N L+G L$ in full water saturation zone taking into account the content of clay minerals by $\mathrm{GL}$ is determined as

$$
\phi^{\mathrm{nn}+\gamma}=\phi^{\mathrm{nn}}-\omega_{\mathrm{cl}} K_{\mathrm{cl}} .
$$

Taking into account relation (6), the porosity by NNL+GL can be obtained in the following form:

$$
\phi^{\mathrm{nn}+\gamma}=\frac{\phi^{\mathrm{nn}}-\omega_{\mathrm{cl}} C_{\mathrm{cl}}^{\gamma}}{1-\omega_{\mathrm{cl}} C_{\mathrm{cl}}^{\gamma}},
$$

where $\phi^{n+\gamma}$ is porosity by combination of neutron-neutron and gamma-ray loggings; $\phi^{\text {nn }}$ is porosity by neutron-neutron logging; $\omega_{\mathrm{cl}}$ is hydrogen index of clay minerals; $C_{\mathrm{cl}}^{\gamma}$ is mass content of clay minerals by gamma-ray logging.

Porosity by combination of neutron-neutron and gammaray loggings in aeration zone is apparent; its value is understated because of the reduced value of $\phi^{\mathrm{nn}}$, obtained on the basis of the interpretation dependence of the neutronneutron logging.

In general, the rock porosity by combination of radioactive loggings, $\phi^{\gamma \gamma+n n+\gamma}$, can be represented as

$$
\phi^{\gamma \gamma+\mathrm{nn}+\gamma}=\alpha_{1} \phi^{\gamma \gamma}+\alpha_{2} \phi^{\mathrm{nn}+\gamma}, \quad \alpha_{1}+\alpha_{2}=1
$$

In the full water saturation zone the weight factors are equal $\alpha_{1}=\alpha_{2}=1 / 2$, that is, in this case the porosity by combination of radioactive loggings is expediently taken as the arithmetic mean of porosities $\phi^{\gamma \gamma}$ and $\phi^{n n+\gamma}[19]$.

In the aeration zone porosities $\phi^{\gamma /}$ and $\phi^{n n+\gamma}$ are apparent. Therefore, when determining the true porosity in this zone, formula (17) has the meaning of the weighted arithmetic mean of both apparent porosities with weight factors $\alpha_{1} \approx$ 0,65 and $\alpha_{2} \approx 0,35$. The numerical estimates of weight factors are obtained empirically and confirmed by theoretical calculations $[11,17,20]$.

Volume moisture content. It is determined as the ratio of the volume of water in the pores of the rock to the volume of the rock.
In the zone of full water saturation the volume moisture content coincide with porosity, that is, $W_{V}=\phi$.

In the aeration zone the volume moisture content can be determined in terms of apparent porosities by the GGL and by the NNL+GL as their weighted arithmetic mean [11]

$$
W_{\mathrm{V}}=\beta_{1} \phi^{\gamma \gamma}+\beta_{2} \phi^{\mathrm{nn}+\gamma}, \quad \beta_{1}+\beta_{2}=1,
$$

where the weight factors $\beta$ are estimated empirically: $\beta_{1} \approx 0,10$ i $\beta_{2} \approx 0,90$.

Water saturation. It is determined as the ratio of the volume moisture content to the porosity: $S_{\mathrm{w}}=W_{\mathrm{V}} / \phi$.

In the full water saturation zone, where the moisture content and porosity have the same value, $S_{w}=1$.

In the aeration zone, the water-saturation is equal to [11]:

$$
S_{\mathrm{w}}=\frac{\beta_{1} \phi^{\gamma \gamma}+\beta_{2} \phi^{\mathrm{nn}+\gamma}}{\alpha_{1} \phi^{\gamma \gamma}+\alpha_{2} \phi^{\mathrm{nn}+\gamma}} .
$$

Groundwater level. Full water saturation zone and aeration zone are separated by groundwater level. Difference between density porosity and porosity by combination of neutron-neutron and gamma-ray loggings can serve as identification parameter of aeration zone:

$$
\Delta \phi=\phi^{\gamma \gamma}-\phi^{\mathrm{nn}+\gamma} .
$$

In the full water saturation zone $\Delta \phi \approx 0$, in aeration zone $\Delta \phi>0$; the transition point between these values in depth presents the groundwater level. Above this level, that is, in the aeration zone, the parameter $\Delta \phi$ increases with both increasing true porosity and decreasing water saturation of the rock $[11,17,20]$.

Example of determination of petrophysical parameters.

An example of the application of the developed AMC RL is shown in Fig. 6. The investigated geological section is represented by sandshale rocks, includes an aeration zone and a of full water saturation zone.

Fig. 6 shows mass (1) and volume (3) content of clay minerals; total mass (2) and total volume (4) shaliness; rock density (5); porosity by combination of neutron-neutron and gamma-ray loggings (6); density porosity (7); true porosity in aeration zone and full water saturation zone by combination $\mathrm{NNL}+\mathrm{GL}+\mathrm{GGL}$ (8); volume moisture content (9); water saturation (10).

The borehole section is dissected on lithology; the groundwater level was identified at a depth of $\approx 6,5 \mathrm{~m}$.

The Fig. 6 also shows the experimental points, which are obtained from the data of laboratory investigations of rock samples taken along the borehole section. It can be seen that the logging results are in agreement with the laboratory determinations of the parameters.

Conclusion. The apparatus-methodical complex of radioactive logging for determining the set of petrophysical parameters of near-surface sandshale rocks has been developed.

In the general case, petrophysical parameters (total shaliness, content of clay minerals, density, porosity, volume moisture content, water saturation, groundwater level) can be determined by combining the methods of radioactive logging (gamma-ray logging, neutron-neutron logging, gamma-gamma density logging). The features of obtaining petrophysical parameters in the full water saturation zone and in the aeration zone are shown.

Efficiency of the developed approaches is demonstrated by a concrete example. 


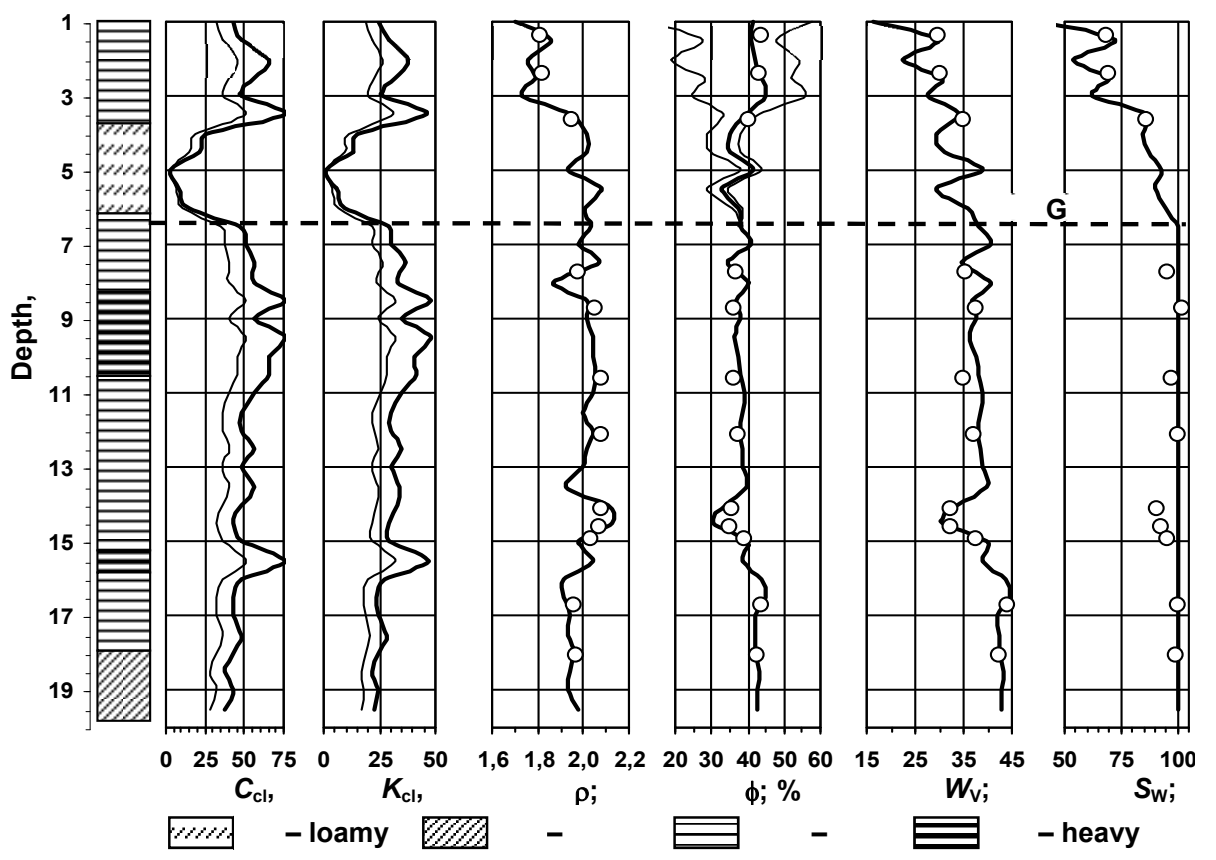

Fig. 6. Example of estimation of lithology and determination of petrophysical parameters with the help of a new apparatus-methodical complex of radioactive logging GWL -groundwater level, 0 - experimental laboratory data

\section{Список використаних джерел:}

1. Влагомер поверхностно-глубинный радиоизотопный ВПГР-1. Техническое описание и инструкция по эксплуатации. - Изд. "Полтава", 1982. $-43 \mathrm{c}$.

2. Добрынин В.М. Петрофизика (физика горных пород) / В. М. Добрынин, Б. Ю. Вендельштейн, Д. А. Кожевников - 2-е изд., перераб. и доп. - М. : ФГУП Изд. "Нефть и газ" РГУ нести и газа им. И.М. Губкина, 2004. -368 c.

3. Интерпретация результатов геосизических исследований нефтяных и газовых скважин. Справочник / под ред. В. М. Добрынина. - М. : Недра, 1988. - 476 с

4. Логвиненко Н.В. Методы определения осадочных пород / Н. В. Логвиненко, Э. И. Сергеева. - Л. : Недра, 1986. - 240 с.

5. Определение емкостных свойств и литологии пород в разрезах нефтегазовых скважин по данным радиоактивного и акустического каротажа / И. В. Головацкая, Ю. А. Гулин, Ф. Х. Еникеева и др. - Калинин, 1984. - $112 \mathrm{c}$.

6. Патент на винахід № 102619 Україна. Багатозондовий прилад радіоізотопного каротажу для дослідження природних і техногенних гірських порід / Кулик В.В., Бондаренко М.С., Євстахевич 3.М., Кетов А.Ю.; заявник і патентовласник ІГФ НАНУ. - № а201115131; заявл. 21.12.11.; опубл. 25.07.13, Бюл. № 14

7. Патент на винахід № 109230 Україна. Спосіб визначення параметрів глинистості гірських порід комплексом радіоактивного каротажу / Кулик В.В., Бондаренко М.С., Дейнеко С.І.; заявник і патентовласник ІГФ НАНУ. - № а201406349; заявл. 10.06.14.; опубл. 27.07.15, Бюл. № 14.

8. Патент на корисну модель № 114892 Україна. Апаратура радіоактивного каротажу для дослідження приповерхневих гірських порід / Кулик В.В., Євстахевич З.М., Бондаренко М.С., Дмитренко О.В.; заявник і патентовласник ІГФ НАНУ. - № u2016 09954; заявл. 29.09.16.; опубл. 27.03.17, Бюл. № 6 .

9. Патент на КМ № 68819. Прилад радіоізотопного каротажу для приповерхневих досліджень / Євстахевич 3.М., Кулик В.В., Кетов А.Ю., Роганін В.В; заявник і патентовласник ІГФ НАНУ. - № u2011 11914; заявл. 10.10.11; опубл. 10.04.12, Бюл. № 7.

10. Патент на КМ № 95931 Україна. Спосіб визначення параметрів густини піщано-глинистих порід комплексом радіоактивного каротажу / Бондаренко М.С., Кулик В.В.; заявник і патентовласник ІГФ НАНУ. № u201408461; заявл. 25.07.14.; опубл. 12.01.15, Бюл. № 1.

11. Патент на КМ № 114871 Україна. Спосіб визначення параметрів приповерхневих гірських порід в зонах аерації і повного водонасичення комплексом радіоактивного каротажу / Кулик В.В., Бондаренко М.С., Докука О.М.; заявник і патентовласник ІГФ НАНУ. - № ч201609703; заявл. 20.09.16.; опубл. 27.03.17, Бюл. № 6.

12. Перспективи ядерно-фізичних методів під час виділення газонасичених порід-колекторів складнопобудованих неогенових відкладів / Д. Д. Федоришин, О. М. Трубенко, С. Д. Федоришин та ін. // Геодинаміка. - 2016. - Т. 21, № 2. - С. 134-143.

13. Плотномер поверхностно-глубинный радиоизотопный ППГР-1. Техническое описание и инструкция по эксплуатации. - Изд. "Полтава", 1986. -60 c.
14. Скважинная ядерная геофизика. Справочник геофизика / под ред. О.Л. Кузнецова и А.Л. Поляченко. - 2-е изд., перераб. и доп. - М. : Недра, 1990.- 318 c.

15. Alexander T. Shale Gas Revolution / T. Alexander, J. Baihly, C. Boyer // Oilfield Review. - 2011. - Vol. 23, № 3. - P. 40-55

16. Bhuyan K. Clay estimation from GR and neutron-density porosity logs / K. Bhuyan, Q.R. Passey // Transactions of SPWLA 35th Annual Logging Symposium, (19-22 June 1994), Tulsa, USA.

17. Bondarenko M. Determination of basic gas reservoir parameters from radioactive logging taking into account PT-conditions / M. Bondarenko, V. Kulyk // NAFTA-GAZ. - 2017. - № 3. - P. 11-17. DOI: 10.18668/ NG.2017.03.

18. Glover P. Petrophysics MSc Course Notes. [Електронний ресурс]/ Leeds University, UK. Режим доступу: www.homepages.see.leeds.ac.uk/ earpwjg/PG_EN/CD\%20Contents/GGL-

$66565 \% 20$ Petrophysics\%20English/ - Назва з екрана

19. Hunt E. Fundamentals of log analysis. Part 8: Determination porosity from density, neutron and acoustic logs / E. Hunt, D. Pursell // World oil - July, 1996. - P. 173-176.

20. Kulyk V.V. Identification of gas reservoirs and determination of their parameters by combination of radioactive logging methods / V.V. Kulyk, M.S. Bondarenko // Геофиз. журнал - 2016. - T. 38, № 2. - С. 106 - 119.

\section{References:}

1. Surface-depth radioisotope moisture meter VPGR-1. Technical description and operation instruction (1982). Publishing house "Poltava". [in Russian].

2. Dobrynin, V.M., Vendelshtein, B.Yu., Kozhevnikov D.A. (2004). Petrophysics (rock physics) (2nd ed.). Moscow: Nedra. [in Russian].

3. Dobrynin, V.M. (Ed.). (1988). Interpretation of results of oil and gas well logging. Handbook. Moscow: Nedra. [in Russian].

4. Logvinenko, N.V., Sergeeva, E.I. (1986). Methods for the determination of sedimentary rocks. Leningrad: Nedra. [in Russian].

5. Golovatckaia, I.V., Gulin, Yu.A., Enikeeva, F.Kh., Velizhanin, V.A., Zhuravlev, B.K., Koziar, V.F., Ruchkin, A.V., Rezvanov, R.A. (1984). The determination of capacitive properties and lithology of rocks in section of oil and gas wells by data of radioactive and acoustic loggings. Kalinin: VNIGIK [in Russian].

6. Kulyk, V.V., Bondarenko, M.S., Yevstakhevych, Z.M., Ketov A.Yu. (2013). UA Patent for invention No 102619. Multi-spacing radioisotope logging tool for investigation of natural and technogenic rocks. Kyiv: Ukrpatent. [in Ukrainian].

7. Kulyk, V.V., Bondarenko, M.S., Deineko, S.I. (2015). UA Patent for an invention No 109230. A method for determining the parameters of shaliness of rock by combination of radioactive loggings. Kyiv: Ukrpatent. [in Ukrainian].

8. Kulyk, V.V., Yevstakhevych, Z.M., Bondarenko, M.S., Dmytrenko O.V. (2017). UA Patent for useful model No 114892. Radioactive logging apparatus for the investigation of near-surface rocks. Kyiv: Ukrpatent. [in Ukrainian].

9. Yevstakhevych, Z.M., Kulyk, V.V., Ketov, A.Yu., Roganin, V.V. (2012). UA Patent for useful model No 68819. Radioisotope logging tool for nearsurface investigation. Kyiv: Ukrpatent. [in Ukrainian]. 
10. Bondarenko, M.S., Kulyk, V.V. (2015). UA Patent for useful model No 95931. Method for determining the parameters of density of sandshale rocks by combination of radioactive loggings. Kyiv: Ukrpatent. [in Ukrainian].

11. Kulyk, V.V., Bondarenko, M.S., Dokuka, O.M. (2017). UA Patent for useful model No 114871. Method of determining the parameters of nearsurface rocks in aeration zone and full water saturation zone by combination of radioactive loggings. Kyiv: Ukrpatent. [in Ukrainian]

12. Fedoryshyn, D.D., Trubenko, O.M., Fedoryshyn, S.D., Ftemov, Ya.M., Koval, Ya.M. (2016). Prospects of nuclear-physical methods when identification of gas-saturated reservoirs of complex structure Neogene deposits. Geodynamika, 21(2), 134-143. [in Ukrainian].

13. Surface-depth radioisotope density meter PPGR-1. Technical description and operation instruction (1982). Publishing house "Poltava". [in Russian].

14. Kuznetcov, O.L., Poliachenko, A.L. (Eds.). (1990). Well logging nuclear geophysics. Geophysicist's handbook. Moscow: Nedra. [in Russian].

15. Alexander, T., Baihly, J., Boyer, C. (2011). Shale Gas Revolution. Oilfield Review, 23(3), 40-55.

М. Бондаренко, канд. геол. наук, ст. наук. співроб., В. Кулик, канд. фіз.-мат. наук, пров. наук. співроб. E-mail: vkulyk@igph.kiev.ua,

3. Євстахевич, пров. інж.

Інститут геофізики ім. С.І. Субботіна НАН України

пр. Палладіна, 32, Київ, 03680, Україна

\section{ПЕТРОФІЗИЧНІ ПАРАМЕТРИ ПРИПОВЕРХНЕВИХ ПІЩАНО-ГЛИНИСТИХ ГІРСЬКИХ ПОРІД ЗА КОМПЛЕКСОМ РАДІОАКТИВНОГО КАРОТАЖУ}

Розроблено апаратурно-методичний комплекс радіоактивного каротажу (АМК РК) для визначення сукупності петрофізичних параметрів приповерхневих піщано-глинистих порід. АМК РК включає: гамма-каротаж (ГК), нейтрон-нейтронний каротаж (ННК) і гамма-гамма каротаж (ГГК); апаратуру РК; інтерпретаційно-методичне і програмне забезпечення.

У загальному випадку петрофізичні параметри гірських порід можна визначити за допомогою комбінування вимірюваних параметрів РК з використанням ряду апріорних даних. АМК РК дозволяє визначати: параметри густини, параметри глинистості, пористість, об:ємний вологовміст, рівень ґрунтових вод та ін. Запропоновано ряд нових способів визначення цих параметрів ядерно-геофізичними методами і показано особливості їх отримання в зоні повного водонасичення та в зоні аерації. Ряд параметрів вперше визначено за допомогою геофізичних свердловинних досліджень.

Розроблено, виготовлено і випробувано комплект двоканальних приладів 2НHК і ГГК+ГК та трикомпонентний прилад 2НHК+ГГК+ГК, які відповідають сучасним вимогам.

Ефективність розроблених підходів і апаратури продемонстрована на прикладі визначення петрофізичних параметрів в обсадженій свердловині.

Ключові слова: приповерхневі гірські породи, петрофізичні параметри, комплекс гамма-, нейтрон-нейтронного і гамма-гамма каротажу; апаратура радіоактивного каротажу, глинистість, густина, пористість, об'ємний вологовміст, коефіцієнт водонасиченості.

М. Бондаренко, канд. геол. наук, ст. науч. сотр.

В. Кулик, канд. физ.-мат. наук, вед. науч. сотр.

E-mail: vkulyk@igph.kiev.ua

3. Евстахевич, вед. инж.

Институт геофизики им. С.И. Субботина НАН Украины

пр. Палладина, 32, Киев, 03680, Украина

\section{ПЕТРОФИЗИЧЕСКИЕ ПАРАМЕТРЫ ПРИПОВЕРХНОСТНЫХ ПЕСЧАНО-ГЛИНИСТЫХ ГОРНЫХ ПОРОД ПО КОМПЛЕКСУ РАДИОАКТИВНОГО КАРОТАЖА}

Разработан аппаратурно-методический комплекс радиоактивного каротажа (АМК РК) для определения совокупности петрофизических параметров приповерхностных песчано-елинистых пород. АМК РК включает: гамма-каротаж (ГК), нейтрон-нейтронный каротаж (ННК) и гамма-гамма каротаж (ГГК); аппаратуру РК; интерпретационно-методическое и программное обеспечение.

В общем случае петрофизические параметры горных пород можно определить с помощью комбинирования измеряемых параметров РК с использованием ряда априорных данных. АМК РК позволяет определять: параметры плотности, параметры елинистости, пористость, объемное влагосодержание, уровень грунтовых вод и др. Предложен ряд новых способов определения этих параметров ядерно-геофизическими методами и показаны особенности их получения в зоне полного водонасыщения и в зоне аэрации. Ряд параметров впервые определен при помощи геофизических скважинных исследований.

Разработаны, изготовлены и испытаны комплект двухканальных приборов 2HнК и ГГК+ГК и трехкомпонентный прибор

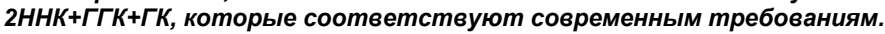

Эффективность разработанных подходов и аппаратуры продемонстрирована на примере определения петрофизических параметров в обсаженной скважине.

Ключевые слова: приповерхностные горные породы, петрофизические параметры, комплекс гамма-, нейтрон-нейтронного и гамма-гамма каротажа; аппаратура радиоактивного каротажа, глинистость, плотность, пористость, объемное влагосодержание, коэффициент водонасыщенности. 